\title{
Kvalitet som masteridé i barnehagesektoren
}

\author{
Kjell-Åge Gotvassli ${ }^{1 \star}$, and Berit Irene Vannebo ${ }^{2}$ \\ ${ }^{1}$ Nord Universitet/DMMH, Trondheim, Norge; ${ }^{2}$ Nord Universitet, Steinkjer, Norge
}

\section{Sammendrag}

Barnehagesektoren i Norge har gjennomgått mange endringer i de siste årene. Et sentralt trekk har vært satsing på kvalitet. I dette arbeidet tar vi utgangspunkt i translasjonsteori og begrepet masterideer for å analysere det sterke fokuset på kvalitet og kvalitetsutvikling i barnehagesektoren i Norge. I forlengelsen av dette drøfter vi også i hvilken grad kvalitetsreformen har påvirket bruken av ulike ferdige løsninger, «pakker» og kvalitetsverktøy i barnehagen.

Vårt empiriske materiale består av dokumentanalyse, intervju med styrere og to nasjonale surveys til styrere i barnehagen. Et funn hos oss er at konseptet om kvalitet og kvalitetsutvikling i barnehagen kan forstås som en masteridé. Våre data viser også at både styrere og eiere rapporterer om økt tilbud fra mange ulike leverandører av ferdige pedagogiske opplegg og kvalitetsverktøy. Det er likevel slik at det varierer i hvor stor grad og hvordan barnehager tar i bruk ferdige pakker og standardiserte opplegg. Barnehagestyrerne fremstår slik som aktive translatører som forholder seg aktive til sirkulerende reformideer.

\section{Nøkkelord: Barnehagepolitikk; ledelse; translasjonsteori}

\begin{abstract}
The ECEC sector in Norway has undergone many changes in recent years. One key feature has been a commitment to ensure quality of services and learning activities in ECECs. In this article, we rely on organizational theory - and more specifically the concept of master ideas - to analyze the strong focus on quality and quality improvement in the ECEC sector in Norway. More specifically, we discuss the extent to which quality reform has affected the use of various ready-made solutions, "packages" and quality tools in ECECs.

Our empirical material consists of document analysis, interviews with managers and two national surveys of managers in ECECs. Our analyses reveal that the focus on quality assurance and quality in ECECs can be understood as a classical master idea. Our data shows that both managers and owners of ECECs report an increase in the supply of ready-made learning programs and quality assurance tools. Individual ECECs do however vary according to which programs they implement, and ECEC managers are actively interpreting and modifying quality assurance tools to best fit the practices of their individual ECECs.
\end{abstract}

Keywords: ECECs; leadership; translation theory.

Received: August 2015; Accepted: January 2016; Published: April 2016

^Korrespondanse: Kjell-Åge Gotvassli, Nord Universitet, Postboks 2501, Steinkjer, E-post: kjell.a.gotvassli@nord.no 


\section{Bakgrunn - økt fokus på kvalitet}

Barnehagesektoren i Norge har gjennomgått store endringer de siste to tiårene. Siden barnehageforliket i 2003 har om lag 80000 flere barn fått barnehageplass, de offentlige tilskuddene har økt, antall ansatte har økt og foreldrebetaling har blitt kraftig redusert. I dag har vi tilnærmet full barnehagedekning der 97 prosent av femåringene har barnehageerfaring før skolestart (Meld. St. 24 (2012-2013) Framtidens barnehage; Utdanningsdirektoratet - Barnehagespegelen, 2014).

Parallelt med den store ekspansjonen i sektoren har det oppstått en diskusjon omkring kvaliteten på tilbudet i barnehagen. Spørsmålet har vært i hvilken grad fokus på kvantitet - økning av antallet barnehageplasser - går ut over det tilbudet barna får i barnehagen. Dette er en debatt både politikere og fagfolk har engasjert seg i (Sommersel, Vestergaard \& Larsen, 2013). Stortingsmelding nr. 27 (1999-2000) Barnehager til beste for barn og foreldre er et klart eksempel på hvordan kvalitet fremheves i denne debatten. Stortingsmeldingen stiller krav til kvalitet der både barnas og foreldrenes behov blir tydeliggjort, og det legges særlig vekt på viktigheten av et kompetent personale for å sikre et kvalitativt godt tilbud.

Andre sentrale dokumenter tar også opp bekymringen om kvaliteten i bernehagetilbudet er god nok. Særlig da St. meld. Nr. 41 (2008-2009) Kvalitet $i$ barnehagen, NOU 2012: 1 Til barnas beste - Ny lovgivning for barnehagene og Meld. St. 24 2012-2013 Framtidens barnehage. I alle disse dokumentene legger regjeringen frem kvalitetsfremmende tiltak med formål «å sikre likeverdig og høy kvalitet i alle barnehager, styrke barnehagen som læringsarena og at alle barn skal få delta aktivt i et inkluderende fellesskap» (Meld. St. 24 (2012-2013) Framtidens barnehage). Evalueringer av kvaliteten i de norske barnehagene blir blant annet tatt opp i Rapport IRIS - 2011/029 Barnehagens organisering og strukturelle faktorers betydning for kvalitet og NOVA Rapport 1/13 Kvalitet $i$ barnehager.

Mange planverk på kommunalt nivå har også fokus på kvalitet som overordnet tema. Bergen kommune har for eksempel utarbeidet: Kvalitetsutviklingsplan for barnehagene $i$ Bergen 2013-2016 - Sammen for kvalitet.

Den faglige debatten om kvalitet i barnehagen har også vært levende og sterk i alle disse årene. Allerede i 1993 kom boken med tittelen Total kvalitetsledelse $i$ barnehagen (Tofte, 1993) som diskuterer hvordan man må sette krav til ledelse for å få kvalitet i barnehagen. Barne- og familiedepartementet bevilget også i 2001-2003 penger til en rekke kvalitetsprosjekt, og hvor Dronning Mauds Minne Høgskolen (DMMH) fikk ansvaret for delprosjektet med tittel Den norske barnehagekvaliteten. Kvalitetsdiskusjonen har blitt fulgt opp av en rekke prosjekter, rapporter og bøker fra fagmiljøene om ulike sider ved kvalitet i barnehagen, og særlig da sammenhengen mellom personalets kompetanse og kvalitet i barnehagen (Kvistad \& Søbstad, 2005; Schei \& Kvistad, 2012; Sommersel, Vestgaard \& Larsen, 2013; Gotvassli, 2013). En siste indikasjon på at kvalitet er sentralt i debatten omkring utvikling av barnehagesektoren, er Norlandia Care Groups beslutning om at en fra 2014 vil innføre kvalitetssikring av barnehager gjennom en Total Quality Management-prosess og ISO-sertifisering (http:/capella. norlandiabarnehagene.no/Innhold/Nyhet/33771). 
Som vi ser har det fra ulike hold vært stor interesse for å forbedre kvaliteten i norske barnehager gjennom ulike typer kvalitetsreformer i barnehagesektoren. I denne artikkelen bruker vi organisasjonsteori for å analysere hvordan reformideer spres og implementeres, og diskuterer hvordan kvalitetsreformen har tatt form og spredd seg i barnehagesektoren.

\section{Reformer som masterideer}

Det har vært et sterkt og langvarig fokus på kvalitet og kvalitetsutvikling i barnehagesektoren i Norge de siste 20 årene. Problemstillingen i denne artikkelen dreier seg hvordan en kan forstå bakgrunnen for og konsekvensene av en slik kvalitetsreform $i$ barnehagesektoren. Før vi presenterer våre forskningsspørsmål vil vi kort se på to perspektiv som kan legges til grunn for ulike forståelser av en reform. I faglitteraturen er det ofte to perspektiver som blir brukt for å analysere reformer i organisasjoner, diffusjonsperspektivet og translasjonsperspektivet (Røvik, 2014).

Diffusjonsperspektivet er et perspektiv som analyserer hvordan reformer og nye praksiser sprer seg innad i, og mellom, organisasjoner. Standardfremstillingen er ofte hentet fra boken The Diffusion of Innovations (Rogers, 1962), der fokuset er på hvordan ny praksis sprer seg gradvis i organisasjonen avhengig av den kraften som en sentral kilde gir til reformideer. En sentral kilde kan være ledere og politikere og hvordan disse aktørene tar aktivt del i å spre en reformidé slik at den over tid vil forankres innad og nå ut til store deler av organisasjonen. Implementeringen er her også betraktet som en planlagt og godt styrt prosess.

Translasjonsperspektivet analyserer bakgrunnen for reformer og viser til at en reformidé ikke nødvendigvis kommer utelukkende fra, og spres via, én sterk sentral kilde. Snarere skjer idéspredning som følge av at alle aktører som mottar og forholder seg aktivt til ideer, tilfører ideene ny spredningskraft. Aktørene har også et mye mer dynamisk forhold til ideene ved at de på ulike måter bearbeider og setter preg på ideene (Latour, 1986).

Ett viktig poeng i dette perspektivet er også at ideer ofte tar form av ferdige organisasjonsoppskrifter (Røvik, 1998). Organisasjonsoppskrifter er immaterielle ideer som «foreskriver nøyaktig hvordan organisasjonen bør være og/eller hvordan bestemte aktiviteter bør utøves» (Røvik, 2007, s. 16). Disse ideene er derimot også ofte generelle og må «tolkes og tydeliggjøres i de enkelte organisasjoner de søkes innpasset i». Ideer tar også form av megatrender eller det som Røvik (2014) kaller masterideer.

Masterideer er populariserte ideer om hvordan moderne organisasjoner skal styres og ledes, hvilket design de skal ha, hvordan planer og rutiner skal utarbeides og iverksettes, og hva slags ledelse som foretrekkes. Sentralt i denne forståelsen er også at organisasjoner tar i bruk ulike typer ferdige løsninger, konsepter og standardiserte fremgangsmåter når reformer skal implementeres. Som eksempel på slike masterideer nevner Røvik (2014, s. 67) bruken av evidensbaserte metoder og evidensbasert praksis. Hovedideen er at intervensjoner i for eksempel barnevern, skole og barnehage må ha basis i vitenskapelig utprøvde metoder. 


\section{Kjell-Åge Gotvassli and Berit Irene Vannebo}

Reformer innebærer ofte fokus på utvikling av ulike kvalitetsverktøy som tillater måling eller evidensbasert dokumentasjon av prosesser og tiltak i organisasjoner. Omfanget av bruken av slike kvalitetsverktøy i en sektor som for eksempel barnevernet er dermed et eksempel på hvordan en type organisasjonsoppskrifter spres, forankres og endrer praksis i profesjoner og organisasjoner (Augdal \& Rotmo, 2013). Ulike aktører er aktivt involverte i å tilpasse, endre og omforme disse ideene, og dette innebærer konkrete utfordringer $\mathrm{i}$ forhold til hvordan implementere omfattende reformer $\mathrm{i}$ sektoren.

\section{Forskningsspørsmål}

Diffusjonsteorien og translasjonsteorien tilbyr altså forskjellige forklaringer på hvordan reformideer oppstår og hvordan reformer gjennomføres. Diffusjonsperspektivet tar utgangspunkt i en rasjonell forklaring der først behovet for endring erkjennes, så defineres behovet for endring og deretter utarbeides reformer som løsninger på ulike utfordringer $\mathrm{i}$ sektoren. Translasjonsperspektivet vektlegger hvordan ulike organisasjonsoppskrifter definerer hvilke konkrete utfordringer sektoren eller organisasjoner står ovenfor, og samtidig tilbyr konkrete løsninger som kan imøtekomme disse utfordringene. Med dette som utgangspunkt har vi valgt å se på følgende forskningsspørsmål:

1. I hvilken grad kan fokus på kvalitet og kvalitetsutvikling i barnehagesektoren forstås som en masteridé?

2. I hvilken grad oversettes masterideer til bruk av ulike ferdige pedagogiske pakker, programmer og kvalitetsverktøy i barnehagen?

3. Hvordan implementerer barnehagestyrerne slike pakker og verktøy?

Dersom det er bruk av kvalitetsverktøy eller av standardiserte løsninger i sektoren, vil det være av stor interesse å se på i hvilken grad disse tas i bruk i barnehagen og ikke minst hvordan de tas i bruk. Kopieres ferdige løsninger og fremgangsmåter, eller skjer det, som translasjonsteorien skisserer, en oversetting gjennom modifisering eller radikal endring av løsninger og verktøy (Røvik, 2007)?

\section{Teoretisk forankring}

En vanlig forståelse innen organisasjonsteorien er at reformer har utgangspunkt i klart definerte problemer og at valgte løsninger etter hvert sprer seg - gjennom diffusjon innad i, og utover, organisasjonen. Hvor fort dette skjer, vil blant annet være avhengig av ideens opphav, og av sentrale drivkrefter bak ideen. Rask adoptering av nye ideer er blant annet avhengig av et visst minsteantall personer som går foran og fronter endringsinitiativ før et større antall følger opp. Begrepene innovatører, tidlige adoptører, tidlig majoritet, sein majoritet og etternølere blir brukt til å beskrive omfanget av, og gjennomføringen av, reformideer (Rogers, 1962). 
Som et alternativ har flere etter hvert lansert ideen om at reformideer utarbeides, spres og iverksettes gjennom translasjonsprosesser (Czarniawska \& Sevon, 1996; Røvik, 1998, 2014; Latour, 1986). Her arbeider de ulike aktørene aktivt opp mot gjennomføring av reformen, hvilket de kan giøre gjennom å yte motstand eller gjennom å aktivt ta del i å utforme endringsinitiativ og gi ideer ny retning i organisasjonen. Dette er for øvrig et perspektiv som Van Meter \& Van Horn (1975) lanserte i sin klassiske artikkel fra 1975 - The policy implementation process: A conceptual framework. Deres hovedpoeng er at vellykket implementering er avhengig av mange faktorer slik som mål for politikken, ressurser hos både initiativtaker og mottaker, karakteristiske trekk ved organisasjoner, kommunikasjonen mellom de organisasjoner som blir berørt og de sosioøkonomiske omgivelsene som organisasjonene befinner seg i.

Slik blir ideene oversatt både når, og som følge av at, de blir spredt. Sentralt i translasjonsperspektivet er også at mange ideer samtidig frembringer løsninger som ofte fremtrer som standardiserte organisasjonsoppskrifter. Disse organisasjonsoppskriftene viser til sentrale utfordringer i moderne organisasjoner og tilbyr konkrete løsninger på hvordan organisatoriske problemer skal angripes. Eksempel på slike organisasjonsoppskrifter er mål- og resultatstyring, og kvalitetsledelse (Røvik, 2014).

\section{Masterideer}

I sin siste bok Reformideer $i$ norsk skole har Røvik (2014) tatt i bruk betegnelsen masteridé om slike organisasjonsoppskrifter. Med masteridé menes en idé som i en periode har fått særlig stor utbredelse og legitimitet og som samtidig gir legitimitet og virker utløsende for lokale reformer i organisasjoner på tvers av sektorer og nasjoner.

Masterideer har en rekke karakteristika. De har stor utbredelse og uklare opphav. Mål og resultatstyring er for eksempel svært vide konsepter som er tatt i bruk $i$ både privat og offentlig sektor, men samtidig er det mange varianter, og opphavet til konseptene er vanskelig å identifisere. Ideene er også selvbegrunnende og institusjonalisert. En masteridé som satsing på kvalitet og kvalitetsutvikling er vanskelig å argumentere imot, slik er det tatt for gitt at dette er en fornuftig måte å forbedre en organisasjon på (Meyer \& Rowan, 1977). Masterideer er også ofte med på å utløse reformer. Det henger sammen med at slike ideer ikke bare betraktes som løsninger, men også som sirkulerende tidstypiske problembeskrivelser for organisasjoner. Til forskjell fra konkrete organisasjonsoppskrifter er masterideene ofte mer strekkbare, upresise og eklektiske. Kvalitet, kvalitetsledelse og Total Quality Management har ulike utforminger, og å definere hva som er kvalitet i et barnehagetilbud, viser seg å være svært vanskelig (Kvistad \& Søbstad, 2005).

\section{Spredningskraft}

At disse masterideene etter hvert får så stor spredningskraft, skyldes ofte at de fremstår som universelle og anvendbare. De blir også båret frem av at de fremstår som rasjonelle og vitenskapelig baserte metoder og fremgangsmåter. I skole og barnehagesammenheng ser det ut til at visse typer vitenskapelige studier - såkalte metastudier basert på oppsummering av mange studier - tillegges stor autorativ kraft. Debatten om boken Visible Learning (Sjøberg, 2015) viser for eksempel at mange norske skolepolitikere 
baserer sin utforming av den lokale skolen med basis i disse studiene. Masterideene knyttes også positivt opp mot ulike kjente aktører, nettverk og institusjoner med høy autoritet og anerkjennelse. I skole- og barnehagesektoren i Norge kan det se ut som for eksempel OECDs studier tillegges en svært sterk sosial autorisering (Karlsen, 2014; Sjøberg, 2015, 2014).

Det at masterideer og organisasjonsoppskrifter har så stor spredningskraft og tas i bruk, kan forklares på ulike måter (Czarniawska \& Sevon, 2005; Røvik, 1998, 2010). For det første kan en anvende en enkel rasjonell begrunnelse. Organisasjonen har definert sine problemer og søker aktivt etter løsninger som kan brukes. En foretar så etter en bevisst vurdering et valg av en eller flere organisasjonsoppskrifter som en mener vil løse problemene.

\section{Oversetting}

Som vi har vist, er det litt ulike forklaringer på hvorfor masterideer og organisasjonsoppskrifter blir tatt i bruk. Vi skal nå kort se litt på ulike måter disse konseptene blir tatt $i$ bruk. Hvordan og i hvilken grad foregår det en oversettelse av ideer, konsepter og fremgangsmåter når det blir tatt i bruk i den enkelte organisasjon? Forskningen viser at dette kan skje på mange ulike måter (Røvik, 2007, 2014). Det kan enkelt skje ved en ren reproduksjon eller kopiering. Konseptet med medarbeidersamtaler skjer her helt $\mathrm{i}$ tråd med den som manualen fra konsulentbyrået anbefaler. Det kan også skje en modifisering, en henter mye av ideen og intensjonen, men selve verktøyet må for eksempel tilpasses barnehagen som organisasjon, i form av andre spørsmål og antall spørsmål i utformingen av medarbeidersamtaler tilpasset den enkelte barnehage. En tredje variant er en radikal modus, her genererer ideen eller konseptet inspirasjon til å utvikle egne løsninger. Å ha planlagte og systematiske samtaler med sine medarbeidere oppleves som en god idé, men ut fra dette utformes det en egenartet måte å giøre dette på i barnehagen.

\section{Det empiriske grunnlaget}

Vi har brukt en rekke datakilder $\mathrm{i}$ vårt arbeid. For det første har vi en dokumentgjennomgang av sentrale dokumenter fra OECD, departementer, Utdanningsdirektoratet, Fylkesmannen, kommuner og barnehager. Hensikten er her å få en oversikt over i hvilken grad disse dokumentene har kvalitet og kvalitetsutvikling som sentralt tema.

En annen kilde er intervju med 10 barnehagestyrere i Midt-Norge gjennomført våren 2013. Informantene representerer både små og mellomstore barnehager, og private og offentlige barnehager.

En tredje viktig kilde er en survey gjennomført høsten 2013 til et representativt antall styrere $(\mathrm{N}=1310)$ i barnehagene i Norge. I dette spørreskjemaet var det en del spørsmål som tok opp i hvilken grad og hvordan styrerne i barnehagen brukte standardiserte, pedagogiske «pakker» og opplegg i sitt arbeid. Metodiske forhold ved både intervju og spørreskjema er nærmere beskrevet i flere artikler (Gotvassli, 2013; Vannebo \& Gotvassli, 2014). 
En siste datakilde er en studie gjennomført av Trøndelag Forskning og Utvikling (TFoU) Spørsmål til Barnehage-Norge i 2014 (TFoU 2015: 1). Undersøkelsen er gjort etter oppdrag fra Utdanningsdirektoratet og inneholder blant annet spørsmål til både styrere og eiere angående bruk av kvalitetsutviklingsverktøy i barnehagen.

Denne tilnærmingen har gitt oss et bredt utvalg av data, men sammenstillingen av dataene byr på en del utfordringer. En viktig begrensning er at begrepsbruken og spørsmålene som er stilt varierer når det gjelder bruken av verktøy og «ferdige pakker» i barnehagen. I vårt eget spørreskjema var betegnelsen «ferdige pedagogiske opplegg/ pakker fra andre i sitt arbeid med barnehagen som læringsarena» brukt for å beskrive kvalitetsverktøy, mens i undersøkelsen fra TFoU ble kvalitetsverktøy forklart som verktøy og metoder som skal bidra til refleksjon, vurdering og utvikling av barnehagens praksis. En var ikke ute etter verktøy som brukes til å kartlegge enkeltbarns ferdigheter. Fritekstkommentarer og bruk av kategorien annet i spørreskjemaet kan likevel tyde på at til tross for presiseringen i forkant av spørsmålet, om at verktøy for kartlegging av enkeltbarns ferdigheter ikke inngikk i spørsmålet, er det flere som nevner kartleggingsverktøy for enkeltbarn slik som TRAS og Alle med. Svarene på vårt eget spørreskjema, svarene i intervjuene og svarene på kartleggingen fra TFoU illustrerer derfor at ferdige pakker, pedagogiske opplegg, kvalitetsverktøy og metoder brukes og oppfattes på mange forskjellige måter i barnehagen.

\section{Resultater}

Våre funn er basert på analyser av både sentrale dokumenter om kvalitet i barnehagesektoren, intervju med 10 barnehagestyrere, en nasjonal representativ spørreundersøkelse til styrere i Norge og en spørreundersøkelse til styrere utført av Trøndelag Forskning og Utvikling.

\section{Dokumentanalyser}

Det har blitt publisert en rekke Stortingsmeldinger, NOU rapporter, evalueringsrapporter og andre dokumenter som har kvalitet og kvalitetsutvikling i barnehagen som sentralt tema. En har særlig vært opptatt av forholdet mellom kvalitet og kvantitet (se for eksempel «Kvalitet og kvantitet: Kvalitet $i$ en barnehagesektor $i$ sterk vekst» NOVA $\mathrm{nr} .2 / 2009)$ og personalets kompetanse som den viktigste faktoren for kvalitetsutvikling ( Strategi for kompetanseutvikling i barnehagesektoren 2007-2011», Kunnskapsdepartementet). Et gjennomgående tema i Rammeplan for barnehagens innhold og oppgaver (2006) er at den skal sikre alle barn et likeverdig og et kvalitativt godt barnehagetilbud.

Fokus på kvalitet er også gjennomgående i OECDs rapporter om barnehagesektoren i Norge. I rapportseriene Starting Strong I, II og III (OECD, 2001, 2006, 2012) og Encouraging Quality in Early Childhood Education and Care (OECD, 2011) og Quality Matters in Early Childhood Education and Care Norway (OECD, 2013) er det en grundig giennomgang av ulike kvalitetsindikatorer i barnehagene i Norge, som også blir sammenlignet med lignende indikatorer $i$ andre land. OECD gir mye ros for kvalitetsarbeidet som er gjort på barnehagesektoren, men anbefaler - med henvisning til blant annet New Zealand og Sverige - utvikling av tydeligere mål og resultatindi- 
katorer for å måle kvalitet, en sterkere sammenheng mellom rammeplanen og skolens læreplaner og en utvikling av en bedre vurderingspraksis for å møte intensjonene $\mathrm{i}$ rammeplanen (OECD, 2013, s. 43).

På lokalt hold er det også en klar tendens til at plandokumenter tar opp i seg kvalitetsbegrepet. I stedet for strategisk plan eller overordnet plan brukes ofte formuleringer som «Kvalitetsplan for de kommunale barnehagene i Sandnes» eller «Kvalitetsutviklingsplan for barnehagene i Bergen 2013-2016. Sammen for kvalitet». I årsplanene for den enkelte barnehage finner vi også ofte henvisninger til og formuleringer om kvalitet. I årsplanene for barnehagene i Øvre Eiker kommune et det et eget punkt om «Kvalitet i barnehagen - Barnehagen som lærende organisasjon» med henvisning til kommunens «Strategi for økt kvalitet i barnehage».

Dette store fokuset på kvalitet er ifølge Vallberg Roth (2014) et gjennomgående trekk ved sentrale styringsdokumenter i barnehagesektoren i både Norge, Danmark, Finland, Sverige og Island. Men samtidig er det i varierende grad samstemthet i hva som utgjør barnehagekvalitet og om det er bestemte indikatorer som kan legges til grunn for vurdering av kvalitet i barnehagen. Segerholm (2012) viser i en artikkel hvordan begrepet kvalitet blir introdusert rundt år 2000 som det ledende begrepet for vurdering tilbud i barnehage- og skolesektoren. Som hun sier: «We have called this present policy focus on quality in education The Quality Turn ...» (Segerholm, 2012, s. 117). Hun viser også til hvordan begrepet sprer seg og blir ledende i hele sektoren.

... ideas of how to do this are spread between countries. Ideas are transferred, translated, mediated and learned through organizations like the OECD (via e.g. country reviews, PISA), the EU (through e.g. the Lisbon Strategy), and the SICI (The Standing International Conference of Inspectors).

\section{Intervjuene}

I intervjuene vi hadde med barnehagestyrerne ble tematikken ofte brakt på bane av styrerne selv i tilknytting til arbeid med den pedagogiske lederrollen. I alle kommunene som er representert, er det slik at kvalitet og kvalitetsutvikling blir fremholdt som et bærende prinsipp for utvikling av barnehagene. Styrerne er i hovedsak positive til en felles satsing på temaer og opplegg, men de legger vekt på at det må være rom for lokale varianter og prioriteringer. Det er derfor relativt stor skepsis til strukturerte opplegg med klare «oppskrifter» og detaljerte mål. Et eksempel på dette er følgende:

«Jeg er veldig redd for mye strukturerte planer og for mye målinger og for mye for at unger er unger og unger er forskjellige».

Det er et viktig poeng for samtlige intervjuede at egen og barnehagens kompetanse og særegenhet blir anerkjent og at det er frihet til at en kan bearbeide slike opplegg og tilpasse det til egen barnehage. En styrer uttrykker seg slik:

Vi har samarbeid med skolen om engelsk - opplegget heter Teddy. Men vi bruker det bare for de eldste barna. Det er et «skoleopplegg» samtidig som vi har gjort det til vårt eget ... Vi har laget litt flere bilder, endret litt på teksten og «fletter» det inn $\mathrm{i}$ andre temaer vi arbeider med. Er det frukt så tar vi bilde av Teddy med frukt ... 
Vi ser her viktigheten av at en kan hente ideer fra et slikt opplegg, men samtidig integrere disse inn i etablert praksis i barnehagen, dvs. giennom omfattende bruk av oversettelse, og modifisering av oppleggene.

Styrerne opplever videre at det har vært en sterk økning av ferdige pedagogiske opplegg som tilbys fra ulike aktører. Særlig ser det ut som antallet kommersielle leverandører har økt, og det kan være vanskelig å vurdere kvaliteten på disse oppleggene. Mange fremhever for øvrig de gode oppleggene som kommer fra ideelle organisasjoner som Redd Barna, Røde Kors og Redningsselskapet.

\section{Spørreskjema}

Som sagt hadde vi i vårt eget spørreskjema en del spørsmål som tok opp bruken av ferdige pakker og opplegg i barnehagen. Et sentralt spørsmål er i hvilken grad slike ferdige pakker og opplegg blir tatt i bruk. Resultatene slik som styrerne selv svarer, er at $23.7 \%$ sier i liten grad, mens $65.3 \%$ sier i noen grad og $10.8 \%$ i stor grad tabell 1 .

De svar som respondentene har gitt gir en god indikasjon på at slike ferdige pakker og opplegg for en god del er i bruk i barnehagen, men det sier lite om hva de faktisk består av.

Et annet viktig poeng i translasjonsteorien er om, i hvilken grad og hvordan det skjer en kopiering, oversetting eller tilpasning av verktøy og metoder når det brukes i egen barnehage. Svarene gjengitt i tabell 2 viser at det i stor grad skjer en slik tilpasning. Bare $2.4 \%$ sier at de brukes uten endringer, mens $28.7 \%$ sier at de kun henter ideer og utarbeider resten selv.

At styrerne selv oppfatter at de har handlingsrom her, blir understreket av data fra spørreundersøkelsen som ble gjennomført av TFoU. Dette fremgår av tabell 3. Styrerne gir her til svar at det i ca. 1/3 eller mer av tilfellene er slik at det er barnehagen selv som bestemmer bruken av ulike typer kvalitetsverktøy. Når det gjelder bruken av verktøy for systematiske barnesamtaler, oppgir $83 \%$ av styrerne at det er barnehagen selv som har bestemt dette. Dette kan kanskje tolkes som at disse verktøyene er utviklet lokalt og at barnehagen har faste rutiner på å ta i bruk disse hvert år.

Uten å gå i detaljer kan vi også ta med fra TFoUs undersøkelse at kvalitetsverktøyene i stor grad får godt skussmål fra de som benytter dem. De gir både nyttig informasjon og oppleves nyttig som bidrag til endring av praksis. Både kvalitet, pris og tilgjengelighet til kvalitetsverktøyene synes å, påvirke bruken av dem. Det som gir

Tabell 1. Svarfordeling på spørsmålet: I hvilken grad tar din barnehage i bruk ferdige pedagogiske opplegg/pakker fra andre i sitt arbeid med barnehagen som læringsarena for barn?

\begin{tabular}{lcr}
\hline Svaralternativer & Antall $(\mathrm{N})$ & Prosent \\
\hline I liten grad & 310 & $23.7 \%$ \\
I noen grad & 853 & $65.3 \%$ \\
I stor grad & 141 & $10.8 \%$ \\
Vet ikke & 2 & $0.2 \%$ \\
Totalt & 1306 & $100 \%$ \\
\hline
\end{tabular}




\section{Kjell-Age Gotvassli and Berit Irene Vannebo}

Tabell 2. Svarfordeling på spørsmålet: Hvordan tar dere i bruk disse ferdige oppleggene/pakkene?

\begin{tabular}{lrr}
\hline Svaralternativer & Antall (N) & Prosent \\
\hline Bruker de uten endringer & 30 & $2.4 \%$ \\
Gjør en del endringer slik at de tilpasses vår barnehage & 436 & $34.4 \%$ \\
Henter ideer fra disse pakkene, men utarbeider resten selv & 363 & $28.7 \%$ \\
Tilpasning og bruk av slike pakker varierer mye & 416 & $32.9 \%$ \\
Vet ikke & 21 & $1.7 \%$ \\
Totalt & 1266 & $100 \%$ \\
\hline
\end{tabular}

størst utslag for barnehagestyrerne er mangel på tid rådighet i barnehagehverdagen (Sivertsen m. fl., 2014, s. 21).

\section{Oppsummering}

Vi har foretatt en dokumentanalyse, vi har data fra en mindre intervjuundersøkelse og data fra to relativt ferske spørreundersøkelser. Litt av utfordringen med analysen av disse datakildene er at de er designet til litt ulike formål og at begrepsbruken ikke er helt konsistent. Det blir brukt både begrep som kvalitetsverktøy, ferdige pedagogiske opplegg, ferdige pakker etc. og de blir også delvis knyttet til ulike sider ved en barnehages virksomhet, slik som kvalitetsarbeid eller barnehagen som læringsarena for barn.

Samlet sett gir dataene likevel et bilde av at ulike typer verktøy, ferdige opplegg og ferdige pakker er $i$ bruk $\mathrm{i}$ barnehagen, og at styrerne selv mener at de $\mathrm{i}$ en viss utstrekning bestemmer over hva som skal brukes og ikke minst hvordan de skal bruke det. Oppfatningen er at styrerne selv mener at det skjer en sterk grad av endring og tilpasning av disse oppleggene og i svært liten grad ren kopiering. Slik fremstår styrerne som aktive translatører av standardiserte løsninger. Men vi har liten innsikt i hvordan translasjoner i praksis gjøres, hvilke prosesser som skjer i barnehagen og hvordan styreren foretar slike tilpasninger. Vi vet heller ikke så mye om hvilke ferdige pedagogiske programmer og pakker som pålegges styrerne. Slike pålegg oppleves ofte

Tabell 3. Styrernes oppfatning av hvem som har bestemt bruken av kvalitetsverktøyet.

\begin{tabular}{|c|c|c|c|c|c|}
\hline & Barnehageeier & $\begin{array}{l}\text { Kommunal } \\
\text { myndighet }\end{array}$ & $\begin{array}{l}\text { Barnehagen } \\
\text { selv }\end{array}$ & $\begin{array}{l}\text { Andre } \\
\text { aktører }\end{array}$ & $\begin{array}{l}\text { Antall } \\
(\mathrm{N})\end{array}$ \\
\hline Udirs Ståstedanalyse & $34.4 \%$ & $30.5 \%$ & $35.1 \%$ & $0.0 \%$ & 131 \\
\hline $\begin{array}{l}\text { PULS barnehage eller andre } \\
\text { prosessverktøy }\end{array}$ & $22.0 \%$ & $39.0 \%$ & $36.6 \%$ & $2.4 \%$ & 41 \\
\hline Foreldreundersøkelse & $34.7 \%$ & $33.5 \%$ & $31.8 \%$ & $0.0 \%$ & 799 \\
\hline $\begin{array}{l}\text { Verktøy for systematiske } \\
\text { barnesamtaler }\end{array}$ & $8.1 \%$ & $8.5 \%$ & $82.9 \%$ & $0.5 \%$ & 211 \\
\hline Ekstern vurdering & $36.5 \%$ & $29.9 \%$ & $32.1 \%$ & $1.5 \%$ & 137 \\
\hline Annet & $18.5 \%$ & $17.3 \%$ & $63.6 \%$ & $0.6 \%$ & 162 \\
\hline
\end{tabular}


som et klart brudd med metodefriheten og blir derfor heftig diskutert (Pettersvold \& Østrem, 2012).

\section{Drøfting og konklusjoner}

I denne delen vil vi vende tilbake til problemstillingene og si litt om våre funn $\mathrm{i}$ tilknytning til dette. Hva er det vi har fått som svar?

\section{Utgangspunkt for studien}

Vi igangsatte denne studien for å undersøke i hvilken grad translasjonsteori og begrep som organisasjonsoppskrifter og masterideer er nyttige for å analysere fremveksten av det sterke fokuset på kvalitet og kvalitetsutvikling i barnehagesektoren i Norge. Med dette som utgangspunkt har vi stilt spørsmålet om fokus på kvalitet og kvalitetsutvikling i barnehagesektoren kan forstås som en masteridé? Som en iscenesetting av denne kvalitetssatsingen testingen ønsket vi også å se på bruken av ulike ferdige pedagogiske pakker, programmer og kvalitetsverktøy i bruk i barnehagen, og hvordan barnehagestyrerne implementerer slike pakker og verktøy.

Translasjonsperspektivet utfordrer den rasjonalistiske tankegangen der reformer er et resultat av nøyaktige analyser, problemformulering og søken og valg av optimale løsninger, altså godt planlagte og gjennomførte prosesser. Vi vil derfor hevde at translasjonsteori og innsikten om masterideer åpner for en forståelse av at reformideer like mye er løsninger som kommer og «tilbys» før en egentlig har definert hva som er problemet i organisasjonen. Det er denne samtidigheten av mulige løsninger og mulige problemer som skiller seg ut som forklaring i forhold til reformer som er mer rasjonelt drevet.

\section{Kvalitet som masteridé}

Som vi ser det, er konseptet om kvalitet og kvalitetsutvikling i barnehagen en klassisk masteridé. Den har stor og kraftig utbredelse i hele sektoren, helt ifra OECD og ned til den enkelte barnehage. Slik er den også institusjonalisert og selvbegrunnende. Det er ingen som med fornuft kan argumentere mot satsingen på kvalitet. I en analyse av reformideer i norsk skole skriver Røvik også at kvalitet kanskje er den mest typiske masterideen i vår tid og har hatt denne posisjonen siden begynnelsen av 1980-årene (Røvik, 2014, s. 60).

Et annet typisk trekk ved kvalitet som masteridé er at den er svert eklektisk, altså «strekkbar», og det er svært vanskelig å definere hva som er kvalitet i barnehagen. Kvalitet kan for eksempel forståes ut fra ulike posisjoner, fra de ansatte, barna, foreldrenes og eiernes synspunkt. Det er derfor typisk at Utdanningsdirektoratet har brukt mye ressurser på å få innsikt i ulike sider ved kvalitet $\mathrm{i}$ barnehagen. ${ }^{1}$ Et av hovedspørsmålene som skulle besvares, var: Hva er kvalitet? Svaret som gis, er ikke overraskende; at dette er et komplekst begrep og består av minst fire ulike typer

\footnotetext{
${ }^{1}$ Eksempel på en slik studie er Kvalitet $i$ barnehager $i$ skandinavisk forskning 2006-2011 fra Dansk Clearinghouse for Uddannelsesforskning.
} 
kvalitet: resultatkvalitet, innholdskvalitet, prosesskvalitet og strukturell kvalitet. Vi ser her hvor strekkbart og tøyelig kvalitetsbegrepet er.

Kvalitetsbegrepet har også høy status i form av en sosial autorisering fra overnasjonale organer som EU og OECD og nasjonale organer som Kunnskapsdepartementet og Utdanningsdirektoratet. Dette har vært og blir fremdeles støttet opp av en rekke forskningsprosjekter på internasjonal og nasjonal basis. Under programmet Starting Strong $I-I V$ har OECD satt i gang en rekke forsknings- og utredningsprosjekter, og internasjonalt og nasjonalt er det stort fokus på kvalitet i barnehagen. Gjennom den utstrakte forskningen på området kvalitet i barnehagen er også begrepet styrket og vitenskapeliggjort.

\section{Bruken av ulike pedagogiske pakker og kvalitetsverktøy}

En annen problemstilling ved vår studie var å se på $\mathrm{i}$ hvilken grad det blir tatt $\mathrm{i}$ bruk ulike ferdige løsninger, «pakker» og kvalitetsverktøy i barnehagen og hvordan barnehagestyrerne implementerer slike «pakker» og verktøy». Forekomsten og bruken av slike ferdige pakker og verktøy ser vi på som eksempler på hvordan kvalitetsideen blir «iscenesatt», hvordan en prøver å implementere en reformidé og hvordan den på en konkret måte preger den pedagogiske praksisen.

Analysen av våre data viser at både styrere og eiere rapporterer om økt tilbud og mange ulike leverandører av ferdige pedagogiske opplegg, ferdige pakker og kvalitetsverktøy. Godt over $63 \%$ av de spurte styrerne oppgir at de $i$ noen grad tar i bruk slike ferdige pakker, nesten $11 \%$ svarer $i$ stor grad.

Det er altså en aktiv tilbudsside som etter hvert inntar en industrilignende form, noe som er godt kjent i fra skolesektoren (Pettersvold \& Østrem, 2012). Ikke minst har det vært sterk debatt om bruken av pedagogiske programmer som har til hensikt å regulere barns atferd. Program som De utrolige årene brukes i dag i mange barnehager og skoler. Programmene selges inn mot kommuner som evidensbasert - det vil si forskningsbasert, i den forstand at de har dokumentert effekt og virker (Hennum, Pettersvold \& Østrem, 2015).

Det finnes også en stor etterspørselsside. Presset på barnehagene som organisasjon har økt de siste årene både i forhold til krav og ønsker fra foreldrene, den enkelte ansatte, politikere, eiere, skolesektoren, barnevernet og PPT. Alle vil noe med barnehagen og forventer noe fra barnehagen. I en slik situasjon der kravene og forventingene er skyhøye og utfordringene komplekse, vil myndigheter, barnehageeiere og ledere lete etter gode og «enkle» løsninger. Denne letingen etter ferdige løsninger blir så en av drivkreftene bak tilbud om ferdige løsninger.

Denne trenden går ofte sammen med et internasjonalt press der norsk barnehagesektor sammenlignes med andre land og der autorative kilder som OECD peker på hva Norge må gjøre. Et godt eksempel på dette er OECDs anbefalinger i rapporten Quality Matters in Early Childhood Education and Care Norway (OECD, 2013, s. 8) om hvordan Norge kan styrke kvaliteten i barnehagen. Der er det gitt følgende anbefalinger: lag tydeligere mål for læringsutbytte, skap større likhet mellom barnehagens læreplaner (rammeplanen) og skolenes læreplaner. Det er også et ønske om at flere anbefalinger og 
gode eksempler må inn i læreplanen og det må satses mer på utvikling av vurderingsverktøy for å måle om rammeplanens ambisjoner blir oppfylt.

\section{Grad av oversetting}

En siste problemstilling vi ønsket å belyse, var hvordan slike ferdige pakker og opplegg tas i bruk - i hvert fall slik styrerne selv rapporterer at de tar dem i bruk. Analysen av dataene fra både spørreskjema og intervju er ganske entydig. Det foregår i svært liten grad ren reproduksjon eller kopi av oppleggene. Den måten det blir gjort på, er først og fremst av modifiserende art. En henter gierne inspirasjon fra andres praksiser for å oppnå gode resultater, men innser likevel at mye må tilpasses egne planer og opplegg og andre trekk ved egen organisasjon. En kan både legge til og trekke fra elementer i slike ferdige opplegg når en utformer dem i egen barnehage. Det er også noen som klart sier at de kun henter inspirasjon eller ideer i slike opplegg når de utvikler egne løsninger. Det blir derfor en radikal endring eller omvandling. Barnehagestyrerne fremstår slik som aktive oversettere/translatører som forholder seg aktive til sirkulerende reformideer og deres utforming ved hjelp av ferdige programmer og pakker. Det er som translasjonsteorien postulerer, at ulike aktører mottar og forholder seg aktive til reformideen, de bearbeider ideen og setter sitt preg på den. Ideen om kvalitetsutvikling $\mathrm{i}$ barnehagen blir oversatt og spredt videre via styrerne som aktive translatører.

\section{Avslutning}

$\AA$ A betrakte kvalitet og kvalitetsutvikling i barnehagesektoren som en masteridé ser ut til å gi oss både en supplerende og alternativ forståelse av hvordan reformideer drives frem i barnehagesektoren. Vi var særlig interesserte i å se på i hvor stor grad masterideen om kvalitet $\mathrm{i}$ barnehagen har resultert i økt tilbud om, og bruk av, ferdige opplegg og kvalitetsverktøy.

I vår analyse fremstår barnehagestyrerne som relativt autonome oversettere av ferdige pedagogiske opplegg, pakker og kvalitetsverktøy. Vi har ingen god innsikt i hvilken grad de lykkes med en slik oversetting, men vi ser at det skjer en aktiv oversetting. Det er behov for mer innsikt i hvordan slike translasjoner skjer og hvordan disse prosessene oppfattes av ulike aktører i barnehagen, og ikke minst omkring hvordan barnehagemyndigheter og eiere reagerer på den relativt store faglige autonomiteten som driver slike translasjonsprosesser.

Vi vet også lite om hvilken type oversetterkompetanse som kreves for å få til en vellykket implementering av reformideer i barnehagen. Innsikt fra forskning om vellykket implementering i skolesektoren (Røvik, 2014) kan tyde på at vellykket implementering er avhengig av kunnskaper om konteksten ideen kommer fra, slik at en kan foreta en dekontekstualisering. Neste steg er at en har gode kunnskaper om konteksten det skal oversettes til, slik at det kan skje en lokal tilpasning i form av en kontekstualisering. Røvik (2014) viser hvordan disse translasjonsprosessene ser ut i skolesektoren når reformideer skal implementeres i skolen. Disse prosessene viser til hvordan man i praksis overfører og gjenskaper god praksis inn i nye kontekster 


\section{Kjell-Age Gotvassli and Berit Irene Vannebo}

(Røvik, 2014, s. 40). Reformideer endres og tilpasses den konteksten de skal implementeres i (kontekstualisering), og praksis som importeres fra andre kontekster observeres og dekontekstualiseres, hvilket innebærer at den «oversettes til en så god idémessig representasjon som mulig før den eventuelt kan implementeres og forsøkes gjenskapt på hjemmebane». Vi trenger mer kunnskap om gode og dårlige oversettere og oversettelser, og om hva som bidrar til å redusere eller øke sannsynligheten for å lykkes med å overføre og ta i bruk reformideer fra andre kontekster, som skolesektoren, i barnehagen.

\section{Biografi}

Kjell-Åge Gotvassli har en Ph.D. innen organisatorisk læring fra Handelshøiskolen i København. Han er tilsatt som professor i ledelse ved Nord Universitet, Steinkjer og Dronning Mauds Minne, Høgskolen.

Berit Irene Vannebo har en Ph.D. i sosiologi med fokus på organisasjonsendring og organisasjonskultur. Hun er ansatt som 1. amanuensis ved Nord Universitet, Steinkjer. Hennes forskning omhandler tema som ledelse og styring i offentlig sektor, med spesielt fokus på kvalitetsreformer og organisasjons- og profesjonsutvikling i skoleog barnehagesektoren.

\section{Referanser}

Augdal, I. L. G. \& Rotmo, B. (2013). Hvordan oppnå kunnskapsutvikling når kunnskapen sitter $i$ veggene? En studie av kunnskapsutvikling $i$ to barneverninstitusjoner. (Masteravhandling) København/Aarhus: Handelshøiskolen i København/Aarhus Universitet.

Bergen kommune (2013). Sammen for kvalitet. Kvalitetsutviklingsplan for barnehagene Bergen kommune 2013-2016. Bergen: Bergen kommune.

Czarniawska, B. \& Sevon, G. (1996). Introduction. I Czarniawska, B. \& G. Sevon (Red.) Translating organizational change (s. 1-12). Berlin: Walter de Gruyter.

Czarniawska-Joerges, B. \& Sevón, G. (2005). Global ideas: how ideas, objects and practices travel in a global economy. Denmark: Copenhagen Business School Press.

Gotvassli, K-Å. (2013). Boka om ledelse i barnehagen. Oslo: Universitetsforlaget.

Gotvassli, K-Å. \& Moe, T. (2014). Endringsledelse i barnevernet. I Kvello, Ø. \& Moe, T. Barnevernledelse (s. 41-57) Oslo: Gyldendal.

Hennum, B. A., Pettersvold, M. \& Østrem, S. (2015). Profesjon og kritikk. Bergen: Fagbokforlaget.

Karlsen, G. (2014). Internasjonale aktører som premissgivere for norsk utdanningspolitikk med særlig vekt på OECD. I Røvik, K. A. Reformideer i norsk skole (s. 121-146). Oslo: Cappelen Damm Akademisk.

Kunnskapsdepartementet (2006). Rammeplan for barnehagens innhold og oppgaver. Oslo: Kunnskapsdepartementet.

Kunnskapsdepartementet (1999). Stortingsmelding nr. 27 (1999-2000) Barnehager til beste for barn og foreldre. Oslo: Kunnskapsdepartementet.

Kunnskapsdepartementet (2008). St. meld. Nr. 41 (2008-2009) Kvalitet i barnehagen. Oslo: Kunnskapsdepartementet.

Kunnskapsdepartementet (2012). Meld. St. 24 2012-2013 Framtidens barnehage. Oslo: Kunnskapsdepartementet.

Kvistad, K. \& Søbstad, F. (2005). Kvalitetsarbeid i barnehagen. Oslo: Cappelen Akademisk Forlag.

Latour, B. (1986). Science in action. How to follow scientists and engineers through society. Cambridge, Massachusetts: Harvard University Press.

Meter, V. D. S. \& Horn, V. C. E. (1975). The policy implementation process: A conceptual framework. Administration E Society February 1975, 6, 445-488.

Meyer, J. W. \& Rowan, B. (1977). Institutional organizations: Formal structure as myth and ceremony. American fournal of Sociology, 83(2), 40-363.

NOU 2012: 1 Til barnas beste - Ny lovgivning for barnehagene. Oslo: Kunnskapsdepartementet.

OECD (2001). Starting Strong I. OECD Publishing.

OECD (2006). Starting Strong II. OECD Publishing.

OECD (2012). Starting Strong III. OECD Publishing.

OECD (2011). Encouraging Quality in Early Childhood Education and Care (ECEC). OECD Publishing.

OECD (2013). Quality Matters in Early Childhood Education and Care: Norway 2012. OECD Publishing. 
Pettersvold, M. \& Østrem, S. (2012). Mestrer, mestrer ikke. Oslo: Res Publica.

Rogers, E. M. (1962). The Diffusion of Innovations. New York: Free Press.

Røvik, K. A. (2014). Reformideer i norsk skole. Oslo: Cappelen Damm Akademisk.

Røvik, K. A. (2010). Managementtrender. I Praktisk økonomi og finans, Vol. 26, 3-2010, 61-72.

Røvik, K. A. (2007). Trender og translasjoner. Ideer som former det 21. århundrets organisasjon. Oslo: Universitetsforlaget.

Røvik, K. A. (1998). Moderne organisasjoner. Trender $i$ organisasjonstenkningen ved tusenårsskiftet. Bergen: Fagbokforlaget.

Schei, S. H. \& Kvistad, K. (2012). Kompetanseløft. Langsiktige tiltak i barnehagen. Oslo: Universitetsforlaget.

Segerholm, C. (2012). The Quality Turn. Political and Methodological Challenges in Contemporary Educational Evaluation and Assesssment. Education Inquiry, Volum 3, No. 2, fune 2012, 115-122.

Sjøberg, S. (2015). Visible Learning: Ny giv for norsk skole? I Utdanning, 21, 14. desember 2012, 44-47.

Sjøberg, S. (2014). PISA syndromet: Hvordan norsk skolepolitikk blir styrt av OECD. Nytt norsk tidsskrift, nr. 1 (31), 30-43.

Sjøberg, S. (2015). «PISA and Global Educational Governance-A Critique of the Project, its Uses and Implications", Eurasia fournal of Mathematics, Science $\mathcal{E}$ Technology Education, 11(1), 111-127.

Sommersel, H. B., Vestgaard, S. \& Larsen, M. S. (2013). Kvalitet i barnehager $i$ skandinavisk forskning 20062011. København: Dansk Clearinghouse for Uddannelsesforskning.

Tofte, B. (1993). Total kvalitetsledelse i barnehagen. Oslo: Ad Notam Gyldendal.

Sivertsen, H., Haugum, M., Haugset, A. S., Carlsson, E., Nilsen, R. D. \& Nossum, G. (2015). Spørsmål til Barnehage - Norge i 2014. TFoU - rapport 2015: 1. Steinkjer: TFoU.

Utdanningsdirektoratet (2014). Barnehagespegelen. Oslo: Utdanningsdirektoratet.

Utdanningsdirektoratet (2007). Strategi for kompetanseutvikling $i$ barnehagesektoren 2007-2011. Oslo: Utdanningsdirektoratet.

Vallberg - Roth, A-C. (2014). Nordic comparative analysis of guidelines for quality and content in early childhood education. Fournal of Nordic Early Childhood Education Research 1, 1-35.

Vanebo, J. O. (2011). Institusjonell ombygging av staten og offentlig sektor. I Busch, T., Johnsen, E., Klausen, K. K. \& Vanebo, J. O. Modernisering av offentlig sektor. Trender, ideer og praksiser (s. 22-33). Oslo: Universitetsforlaget.

Vassenden, A, Thygesen, J., Bayer, S. B., Alvestad, M. \& Abrahamsen, G. (2011). Barnehagens organisering og strukturelle faktorers betydning for kvalitet. Rapport IRIS - 2011/029. Stavanger: IRIS.

Vannebo, B. I. \& Gotvassli, K-Å. (2014). Barnehagestyreren som strategisk aktør - barnehagen som læringsarena. I Mørreaunet, S., Gotvassli, K-Å., Moen, K. H. \& Skogen, E. Ledelse av en leerende barnehage (s. 77-100). Bergen: Fagbokforlaget.

Winsvold, A. \& Guldbrandsen, L. (2009). Kvalitet og kvantitet. Kvalitet $i$ en barnehagesektor $i$ sterk vekst. NOVA 2/2009. Oslo: NOVA. 